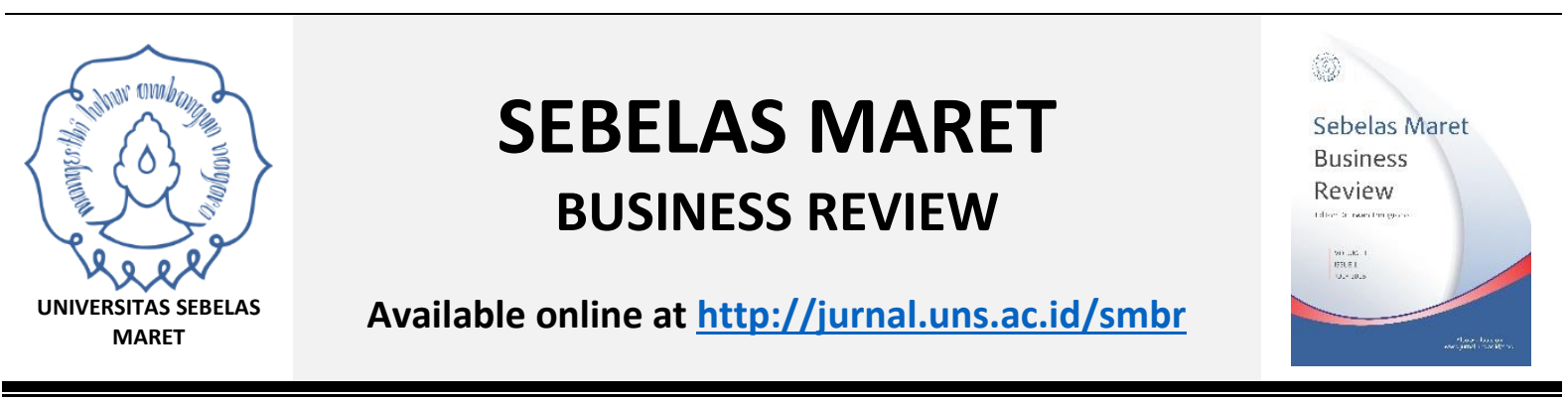

\title{
How the Loyalty of Expedition Business Can Be Formed Through Trust and Satisfaction
}

\section{Esti Nur Wakhidah' ${ }^{1}$ and Budhi Haryanto ${ }^{2}$}

\author{
Faculty of Economics and Business, Universitas Sebelas Maret \\ 1Email: esti.nwakhidah@gmail.com \\ 2Email: budhiharyanto@yahoo.com
}

\begin{abstract}
ARTICLE INFO
ABSTRACT

Article History:

The purpose of this study is to examine the role of satisfaction and trust in mediating the relationship

Received 29 June 2017

Received in Revised

Form

Accepted 6 July 2017

Available online 6 July 2017

Keywords: between service quality and brand image, and customer's intention to be loyal. The data is collected using survey and conducted by distributing questionnaire through a website. Website is selected as a media to distribute th research instrument because today marketplace shows a shift from offline to online platform. This study selected 200 people who have the intention to loyal with Jalur Nugraha Ekakurir (JNE) service as samples. Structural Equation Model (SEM) is statistical method chosen to elaborate the

Service Quality, Brand Image, relationship among the variables. The result of this Customer Satisfaction, Customer Trust, Customer Loyalty research indicates that service quality and brand image have positive and significant effect on satisfaction and trust. In addition, this research also find the mediation effect of satisfaction and trust in shaping customer loyalty. This study also discusses the implications from theoretical, practical, and future research, point of view.
\end{abstract}

\section{INTRODUCTION}

Customer loyalty becomes an interesting topic to be studied because it becomes one of positive attitudes toward a company. Customer loyalty is defined as a commitment to repurchase products consistently in the future (Oliver, 1997). Customer loyalty has a significant influence on the creation and maintenance of competitive advantage in the 
service industry (Saravanakumar and Jayakrishnan, 2014). Conducting a research on loyalty is expected to provide understanding on how loyalty is formed so that it can be useful for companies.

This research model is based on five variables. Customer loyalty is a variable that is conceptualized as a dependent variable. While service quality and brand image are conceptualized as independent variables. Customer satisfaction and customer trust lead to customer loyalty and can mediate the relationship between service quality and brand image, and customer loyalty. Through the model built, this research can provide insight to marketers in order to build a marketing strategy. This is related with the method used to increase customer intention to be loyal by paying attention to service quality and brand image mediated by satisfaction and trust.

Customer loyalty is defined as a commitment to repurchase products consistently in the future (Oliver, 1997). Customer loyalty is formed due to customer satisfaction and trust (Nejad, Firoozbakht, and Taghipoor, 2013). All of these three variables have a positive impact on customer loyalty. Customer satisfaction has a strong impact on customer loyalty (Tu, Wang, and Chang, 2012). Additionally, a study also conclude that belief has a significant effect on customer loyalty (Halim, Swasto, Hamid, and Firdaus, 2014).

Service quality becomes one of the determinants of satisfaction, changes in customer satisfaction can be explained by service quality (Mosahab, Mahamad, and Ramayah, 2010). Therefore Hafeez and Bakhtiar (2012) conclude that to achieve success, the company should focus on building customer loyalty that can be done by offering quality products as well as providing maximum service quality. Service quality also has a positive effect on customer trust (Nejad et al., 2014).

The brand image in this study is also conceptualized into one of the variables that affects customer satisfaction. Previous research conducted by Kambiz and Safoura (2014) shows a fairly positive impact of brand image on customer satisfaction. In addition, Halim et al., (2014) in his research also show a positive impact of brand image on customer loyalty through trust variables.

The modelled variables is expected to provide information to marketers about the variables that can increase customer loyalty. It also provides insight to create strategies to get customer loyalty to JNE. Based on the modelled variables, we can define the research problems related to the proportions in the model. Following are the issues that are related to this research.

\section{THEORETICAL BACKGROUND AND HYPOTHESIS}

\section{Customer Loyalty}

Customer loyalty is a psychological character formed by customer's ongoing satisfaction coupled with emotional bond formed with a service provider that leads to a willing and consistent state of being in a relationship (Rai and Srivastava, 2013). Lovelock, Wirtz, and Mussry (2013) argues that loyalty in a business context is a willingness to constantly use the company's products over the long term. This opinion is also in accordance with Saravanakumar et al., (2014) who suggests that customer loyalty has a very significant effect on the creation and maintenance of competitive advantage in the service industry.

According to Sarwar et al. (2012), most marketers around the world agree that it is not enough to get customers but also to retain customers. For this important purpose, 
customer loyalty plays a virtual role. To achieve higher business growth, companies must increase customer loyalty by providing maximum convenience, value, and service to customers. Therefore, customer loyalty acts as a competitive asset for an organization or a company (Onyancha, 2013).

\section{Service Quality}

Service quality is a perception on the difference between the real service received by individuals with their expectations (Parasuraman, Zeithaml, and Berry, 1988). Service quality is closely related to customer satisfaction. Quality provides a special boost for customers to forge long-term mutually beneficial relationships with the company. This kind of emotional attachment allows the company to understand carefully the specific expectations and needs of their customers (Tjiptono and Chandra, 2011).

High competition and increasingly sophisticated quality of life today can not be avoided by business people. One way to deal with it is to create customer satisfaction through quality improvement, because customers are the main focus when we talk about satisfaction and service quality (Lupiyoadi and Hamdani, 2009). This description leads to the following hypothesis:

\section{H1: Service quality has a positive influence on customer satisfaction.}

According to Doney and Cannon (1997) when a customer trusts a company, he/she has a strong confidence in the quality of the products or services provided by the organization. Trusting an organization is considered far more than loyal to the organization. Meanwhile, according to Danesh, Nasab, and Ling (2012), service providers in some cases may not be able to retain their customers because they are less satisfied. But customer satisfaction itself also cannot ensure long-term commitment from customers to each service provider. In contrast, service providers should think for other factors beyond customer satisfaction, such as trusting customers to retain their customers.

The same argument is also put forward by Morgan and Hunt (1994), they argue that a company also has a target to develop customer trust, not just customer satisfaction. This purpose is used to retain customers/customers in the long run. Customer trust tends to be a strong driver of customer retention Therefore in this study the second hypothesis is: H2: Service quality has a positive influence on customer trust.

\section{Brand Image}

Brand image helps customer to know the information of a product or service so as to generate reason for purchase. Maintaining a good brand image is an important role of corporate marketing strategy and branding strategy (Neupane, 2015). Good brand perception is shaped in the customer's memory and strives to give a good impression in customer's mind. A positive brand image can be considered as company's ability to hold a market position. Customers often form a brand image based on their experience (Onyancha, 2013).

Brand image is important because it occupies an important position in customer's minds. Brand image is often considered as an important factor when evaluating services. Many says that brand image is an important factor affecting customer satisfaction (Chao, $\mathrm{Wu}$, and Yen, 2015). Building brand image is an important function of marketing. The brand image is not only convey the goodwill of the brand to the customers but also persuades them to buy products from the company again and again (Baig and Abdul, 2012) 
Several studies have found that brand image has always contributed to customer satisfaction. The public image of a brand is a mental structure that customers formulate and develop on the basis of certain interpretations in particular product brands (Kambiz and Naimi, 2014). Davies and Chun (2002) find that corporate brand image has an indirect effect on brand loyalty through customer satisfaction. Therefore in this study the third hypothesis is:

\section{H3: Brand image has a positive influence on customer satisfaction.}

Brands are also related to customer trust. Trust is developed in customer's mind after a good experience with a particular product. If the experience is fun, repeat purchases will be made with the assumption that the experience will be the same. Building loyalty to a brand is the main objective of a producer. Customers who are loyal and believe in a brand tend to be fanatical toward the brand. Brand loyalty is a means of personal identification for them (Kimchuk and Sandra, 2007). Therefore in this research the fourth hypothesis is:

\section{H4: Brand image has a positive influence on customer trust.}

\section{Customer Satisfaction}

Customer satisfaction is the overall attitude that is formed based on experience after a customer buys a product or uses the product (Nejad et al., 2014). Another opinion according to Onyancha (2013), in the competitive market conditions customer satisfaction is seen as the main focus and increasingly becomes a key element in the determination of business strategy. Satisfied customers of the product or service are considered important because they are more likely to keep using the product or service and maintain good relationships and recommend the product to others.

In the service environment, customer satisfaction has been seen as a special form of customer attitudes (Oliver, 1997). The basis for true loyalty lies in customer satisfaction where service quality becomes the main input. Lovelock et al. (2013) argue that highly satisfied customers or even favored services tend to be loyal supporters of a company and spread positive news. Therefore in this research the fifth hypothesis is:

H5: Customer satisfaction has a positive influence on customer loyalty.

\section{Customer Trust}

Leonidou, Talias, and Leonidou (2008) explain that, trust is a relationship that sticks between a customer and a company, and trust also involves the employees of an organization. The high level of trust in a multinational and multicultural organization creates productive relationships that ultimately results in long-term benefits for the organization. The relationship between customer trust and loyalty has been put forward by large numbers of expert. Ribbink, Riel, Liljander, and Streukens (2004) argue that when customers have trust in the services and products of a company, this will lead to loyalty. Palvia (2009) believes trust is one of the important mediating factors between the behavior of customers before and after purchasing a product that can lead to longterm loyalty and can strengthen the relationship between both parties.

Harris and Goode (2004) also argue that the role of trust is one of the most important factors in determining customer loyalty. While Doney et al. (1997) argue that trust is a significant intervention factor between the behavior of customers before and after the purchase of certain products. This belief leads to long-term loyalty and makes strong connection between the two parties. Trust is considered as a special psychological state as in the case of loyalty and can only occur in certain circumstances. Therefore in 
this study the sixth hypothesis is:

H6: Customer trust has a positive influence on customer loyalty.

\section{THE RESEARCH MODEL}

Based on the six formulated hypotheses, the relationship among conceptual variables is shown in model below (see Figure 1). It describes the relationship framework of the variables.

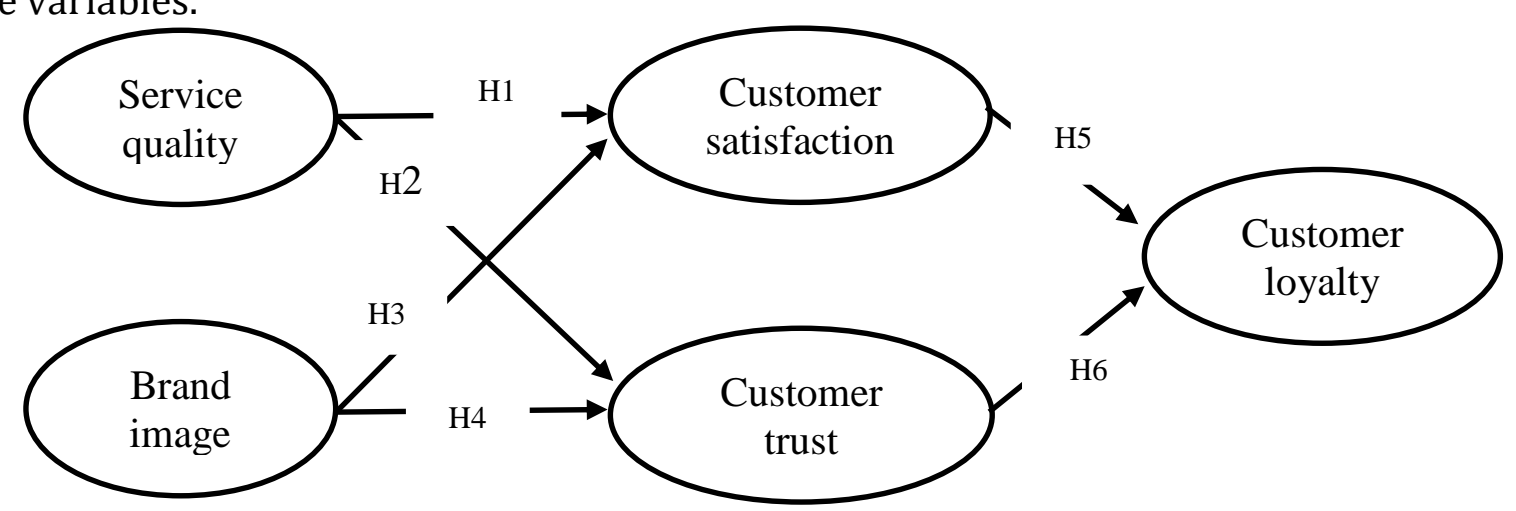

Figure 1. The model of customer loyalty

\section{RESEARCH METHOD}

\section{Data Collection and Sampling Method}

The population of this study is JNE customers who have used JNE more than once and intend to be loyal to JNE. The selected aamples are 200 respondents. Furthermore, the data is collected using questionnaire, which is distributed through online survey platform. This method is selected due to the shift from offline to online market.

\section{The Definition of Variable}

Service quality is the measurement of customer assessment on how far the difference between the real service and their expectations. Parasuraman et al. (1988) proposed an instrument to measure customer perceptions of service quality known as SERVQUAL (reliability, responsiveness, assurance, emphaty, and tangible).

The indicators of service quality in this study are adapted from Parasuraman et al. (1988) and Naik et al. (2010), after goes through minor revision to match with JNE case. Reability is the ability to perform promised and accurate services. Reliability is measured using good, reliable, precise, accurate, and careful items. Responsiveness is the willingness of employees to help customers and provide prompt service. Responsiveness is indicated by quick, sensitive, responsive, attentive, and understanding items. Assurance is the employee's knowledge, courtesy, and their ability to develop customer trust and confidence. Assurance is assessed usingtrusted, safe, experienced, sure, and guaranteed items. Emphaty is the care, understanding, and attention of the waiter given to the customer. Emphaty is measured using questionnaire items: caring, caution, understanding, helpful, and communicative. The tangibles referred to in this dimension include physical attributes, equipment, personnel, and materials prepared. It is measured using questionnaire items: modern, comfortable, attractive, neat, and clean

Brand image is the impression someone has for a brand. Customer attitudes and actions toward a brand are largely determined by the brand image itself. The indicator of 
brand image in this research is adopted from Setyawati \& Budhi (2016) which is lightly revised to match with the situation / phenomenon in this research. The final items used are famous, excellent, good, reputable, and good impression.

Oliver (1997) states that customer satisfaction is expectations before purchase and perceptions about performance after purchase. In the service environment, customer satisfaction has been seen as a special form of customer attitudes. Indicators in this study are adopted from Oliver et al. (1997) and Kotler \& Armstrong (2001), that are satisfied, proud, happy, excited, and exceed expectations.

Trust is a certain amount of customer-specific belief in the company. The indicators used to measure this variable are adopted from Halim et al (2014), Akbar and Som (2011), Ribbink et al. (2004), which are confident, safe, guaranteed, reliable, and honest.

Customer loyalty is customer's intention to reuse a certain product or service so that there is a motivation to continue using it. The indicators used to measure customer loyalty in this study are adopted from Oliver et al. (1997) including intent, will, tend, possible, and commitment.

\section{FINDINGS AND DISCUSSIONS \\ Respondent Profile}

The analysis is conducted in this section to provide information about the characteristic of respondents. Customer profiles consist of six demographic information i.e. age, gender, marriage status, education level, occupation, and monthly income. These demographic information are expected to give the description about customer background (See Table 1). 
Table 1.

Descriptive Statistic

\begin{tabular}{|c|c|c|c|c|}
\hline Item & Category & $\begin{array}{l}\text { Number of } \\
\text { Respondents }\end{array}$ & Frequency & Percentage \\
\hline \multirow{5}{*}{ Age (year) } & $18-22$ & 41 & \multirow{5}{*}{200} & $20,5 \%$ \\
\hline & $22-25$ & 123 & & $60,5 \%$ \\
\hline & $26-29$ & 26 & & $13 \%$ \\
\hline & $30-33$ & 2 & & $2 \%$ \\
\hline & $>33$ & 8 & & $4 \%$ \\
\hline \multirow{2}{*}{ Gender } & Male & 81 & \multirow{2}{*}{200} & $40,5 \%$ \\
\hline & Female & 119 & & $59,5 \%$ \\
\hline \multirow{4}{*}{$\begin{array}{l}\text { Marriage } \\
\text { Status }\end{array}$} & Single & 164 & \multirow{3}{*}{200} & $82 \%$ \\
\hline & Been Married & 2 & & $1 \%$ \\
\hline & Marriage & 34 & & $17 \%$ \\
\hline & Junior high school & 29 & \multirow{5}{*}{200} & $14,5 \%$ \\
\hline \multirow{4}{*}{$\begin{array}{l}\text { Education } \\
\text { Level }\end{array}$} & Diploma & 7 & & $3,5 \%$ \\
\hline & Bachelor degree & 132 & & $66 \%$ \\
\hline & Postgraduate & 31 & & $15,5 \%$ \\
\hline & Etc & 1 & & $0,5 \%$ \\
\hline \multirow{6}{*}{$\begin{array}{l}\text { Occupatio } \\
\text { n }\end{array}$} & Student & 98 & \multirow{6}{*}{200} & $49 \%$ \\
\hline & $\begin{array}{l}\text { Government } \\
\text { employees }\end{array}$ & 8 & & $4 \%$ \\
\hline & Private employees & 58 & & $29 \%$ \\
\hline & Online business & 9 & & $4,5 \%$ \\
\hline & Entrepreneur & 6 & & $3 \%$ \\
\hline & Etc & 21 & & $10,5 \%$ \\
\hline \multirow{5}{*}{$\begin{array}{l}\text { Income } \\
\text { per month }\end{array}$} & Below 1.500 .000 & 97 & \multirow{5}{*}{200} & $48,5 \%$ \\
\hline & $1.500 .000-3.000 .000$ & 57 & & $28,5 \%$ \\
\hline & $3.000 .001-4.500 .000$ & 17 & & $8,5 \%$ \\
\hline & $4.500 .001-6.000 .000$ & 14 & & $7 \%$ \\
\hline & Over 6.000 .000 & 15 & & $7,5 \%$ \\
\hline
\end{tabular}

Based on the research that has been conducted, the majority of respondents are women with 119 people or about $59.5 \%$, while the rest are men with the total of 81 people or about $40.5 \%$. This suggests that women tend to develop loyalty to JNE than men do. Furthermore, by age, the results of this study indicate that most of the respondents are 22-25 years old with the total of 123 respondents or by $60.5 \%$.

Most of respondents have bacheloor degree with the total of 132 people or $66 \%$, while the rest are respondents with other education such as high school graduates, diploma, postgraduate, and others. Respondents' occupation is also a variable that observed in this research. The data showed that 98 people or $49 \%$ are students and the rest are respondents with civil servants, private employees, online business, employers, and other as their occupation. The majority of respondents' income is under 1.5 million rupiah with the total of 97 people or $48.5 \%$.

\section{Validity and Reliability Test}

Validity test is used to determine if questionnaire is valid. The questionnaire is valid if the indicators can reveal the observed variable. This test is conducted using SPSS. In this test, every item must have item factor loading $>0.50$. Furthermore, the reliability test 
using Cronbach's Alpha, with a cut-off values $>0.60$ (Hair et al., 1998) is conducted. The result of validity and reliability testing is summarized in Table 2.

Table 2.

Validity \& Reliability Test

\begin{tabular}{ccc}
\hline & Loading & Cronbach's Alpha \\
\hline Srea 1 &, 652 & \\
Srea 2 &, 775 & \\
Srea 3 &, 718 & 0,870 \\
Srea 4 &, 731 & \\
Srea 5 &, 651 & \\
\hline Sres 1 &, 675 & \\
Sres 2 &, 682 & 0,790 \\
Sres 3 &, 715 & \\
Sres 4 &, 678 & \\
\hline Sass 1 &, 634 & \\
Sass 2 &, 565 & \\
Sass 3 &, 606 & \\
Sass 4 &, 587 & \\
Sass 5 &, 541 & \\
\hline Semp 1 &, 774 & \\
Semp 2 &, 778 & \\
Semp 3 &, 625 & \\
Semp 4 &, 586 & \\
Semp 5 &, 529 & \\
\hline Stan 1 &, 845 & \\
Stan 2 &, 822 & \\
Stan 3 &, 852 & \\
Stan 4 &, 828 & \\
Stan 5 &, 786 & \\
\hline BI 1 &, 741 & \\
BI 2 &, 787 & \\
BI 3 &, 769 & \\
BI 4 &, 775 & \\
BI 5 &, 690 & \\
\hline CS 2 &, 796 & \\
CS 3 &, 774 & \\
CS 4 &, 779 & \\
CS 5 &, 547 & \\
\hline CT 1 &, 525 & \\
CT 2 &, 736 & \\
CT 3 &, 665 & \\
CT 4 &, 683 & \\
CT 5 &, 618 & \\
\hline L 1 &, 765 & \\
L 2 &, 780 & \\
L 3 &, 690 & \\
L 4 &, 741 & \\
\hline & & \\
\hline
\end{tabular}




\section{Goodness of Fit}

The Goodness of Fit test reflects the predicted level of conformity of the model compared to actual data (Ferdinand, 2002). Measurement of goodness of fit conformity is required before testing the hypothesis. The result of goodness of fit in this research can be seen in table 3 .

\section{Tabel 3}

Indeks goodness of fit before modification

\begin{tabular}{lccc}
\hline \multicolumn{1}{c}{ Indeks } & $\begin{array}{c}\text { Cut-off } \\
\text { Value }\end{array}$ & Result & Information \\
\hline$X^{2}$ Chi Square & $\begin{array}{c}\text { Diharapka } \\
\text { n kecil }\end{array}$ & $\begin{array}{c}1567,56 \\
2\end{array}$ & \\
Significance Probabilitas & $\geq 0,05$ & 0,000 & Not Fit \\
RMSEA & $\leq 0,08$ & 0,069 & Fit \\
Goodness of Fit Index (GFI) & $\geq 0,90$ & 0,748 & Not Fit \\
Adjusted Goodness of Fit & $\geq 0,90$ & 0,718 & Not Fit \\
index (AGFI) & $\leq 2,00$ & 1,940 & Fit \\
CMIN/DF & $\geq 0,95$ & 0,867 & Not Fit \\
Tucker-Lewis Index (TLI) & $\geq 0,95$ & 0,876 & Not Fit \\
CFI & & & \\
\hline
\end{tabular}

The result of SEM analysis on the research model showed that only RMSEA and CMIN / DF met the criteria. Thus, this study should be modified to get a better index of goodness of fit index. The final result after the addition of correlation is presented in Table 4.

Table 4

Indeks goodness of fit After Modification

\begin{tabular}{lccc}
\hline \multicolumn{1}{c}{ Indeks } & $\begin{array}{c}\text { Cut-off } \\
\text { Value }\end{array}$ & $\begin{array}{c}\text { Hasil } \\
\text { Model }\end{array}$ & Keterangan \\
\hline$X^{2}$ Chi Square & $\begin{array}{c}\text { Diharapka } \\
\text { n kecil }\end{array}$ & 792,301 & \\
Significance Probabilitas & $\geq 0,05$ & 0,070 & Fit \\
RMSEA & $\leq 0,08$ & 0,020 & Fit \\
Goodness of Fit Index (GFI) & $\geq 0,90$ & 0,855 & Marginal \\
Adjusted Goodness of Fit & $\geq 0,90$ & 0,822 & Marginal \\
index (AGFI) & $\leq 2,00$ & 1,078 & Fit \\
CMIN/DF & $\geq 0,95$ & 0,989 & Fit \\
Tucker-Lewis Index (TLI) & $\geq 0,95$ & 0,991 & Fit \\
CFI & & & \\
\hline
\end{tabular}

The result of after modification analysis shows that several items have met the criteria and only GFI and AGFI that has marginal value. GFI and AGFI are very sensitive to the number of samples, thus, there is a possibility that this marginal result is due to the small number of samples. If the number of samples added then the value of GFI and AGFI will be better / fit (Ferdinand, 2006). In addition, the ability of GFI and AGFI to indicate the suitability of a model is less strong when compared with other indicators, therefore the marginal value of GFI and AGFI can be ignored if other indicators fit the criteria. 


\section{Hypothesis Testing}

After the goodness of fit meet the criteria, then the next stage is to perform hypothesis testing. Based on research that has been conducted with 200 samples, Table 5 below is the result of regression analysis.

Table 5

Regression Weight

\begin{tabular}{|c|c|c|c|c|c|c|}
\hline & & & Estimate & S.E. & C.R. & $\mathrm{P}$ \\
\hline Satisfaction & $<---$ & $\begin{array}{l}\text { Service } \\
\text { Quality }\end{array}$ & 368 & ,054 & 6,841 & *** \\
\hline Trust & $<---$ & $\begin{array}{l}\text { Service } \\
\text { Quality }\end{array}$ & ,233 & ,036 & 6,467 & $* * *$ \\
\hline Satisfaction & $<---$ & $\begin{array}{l}\text { Brand } \\
\text { Image }\end{array}$ & 191 & ,094 & 2,027 & ,043 \\
\hline Trust & $<---$ & $\begin{array}{l}\text { Brand } \\
\text { Image }\end{array}$ & 390 & ,068 & 5,718 & $* * *$ \\
\hline Loyalty & $<---$ & Satisfaction & ,225 & ,060 & 3,760 & $* * *$ \\
\hline Loyalty & $<---$ & Trust & ,616 & ,085 & 7,235 & $* * *$ \\
\hline
\end{tabular}

In this study there are six hypotheses, relationship between service quality with satisfaction, service quality with trust, brand image with satisfaction, brand image with trust, satisfaction with loyalty and trust with loyalty. The following will explain each of these hypotheses.

\section{Relationship between service quality and customer satisfaction}

The result of regression test on the relationship between service quality and customer satisfaction shows that service quality has positive and significant effect on customer satisfaction ( $\beta=0.368 ; \mathrm{S}$. $\mathrm{E}=0.054$; $\mathrm{C} . \mathrm{R}=6.841)$. This can be interpreted that the higher the quality of JNE services, the higher JNE customer satisfaction. The results obtained from this study indicate that service quality and customer satisfaction tend to have a relationship, so $\mathrm{H} 1$ is supported.

This phenomenon supports previous research that the quality of service has a positive effect on customer satisfaction. Previous research by Mosahab et al. (2010), quality of service becomes one of the determinants of satisfaction. Although this study is in different contexts, the results provide the fact that the effect of service quality on customer satisfaction is likely to be a positive ones.

The results of the positive and significant effects can be used as a basis for improving future marketing strategies by JNE. To create customer satisfaction, JNE can deliver promised services, willing to assist customers, and pay attention to the appearance of physical facilities, equipment and company personnel.

\section{Relationship between service quality and customer trust}

The result of regression test on the relationship between service quality and customer trust indicated that service quality had positive and significant influence to customer trust $(\beta=0.233 ; \mathrm{S} . \mathrm{E}=0.036 ; \mathrm{C} . \mathrm{R}=6.467)$. This can be interpreted that the higher the quality of JNE services will leads to the higher customer's trust in JNE. These results indicate that service quality and trust tend to have a relationship, so $\mathrm{H} 2$ is supported. 
This phenomenon supports previous research conducted by Nejad et al. (2014), the results of this study indicate that service quality has a positive impact on customer trust. Although the study is in different contexts, the results provide the fact that the effect of service quality on customer trust is likely to be positive.

The results of the positive and significant effects derived from this research can be used as a basis for improving future marketing strategies by JNE. To create customer trust, JNE can provide fast and accurate services, and give good attention to convince customers.

\section{Relationship between brand image and customer satisfaction}

Regression test result on the relationship between brand image and customer satisfaction indicate that brand image have positive and significant effect to customer satisfaction $(\beta=0.191 ; \mathrm{S}$. $E=0.094 ; \mathrm{C} . \mathrm{R}=2.027)$. This can be interpreted that better the brand image of JNE will leads to the higher customer satisfaction of JNE. The results obtained from this study indicate that brand image and customer satisfaction tend to have a relationship, so that $\mathrm{H} 3$ is supported.

This phenomenon supports previous research conducted by Kambiz et al. (2014), the results show that brand image is proved to have a positive effect on customer satisfaction. Although the context of this study is different but the results provide the fact that the influence of brand image on customer satisfaction tend to be positive.

The results of the positive and significant effects derived from this research can be used as a basis for improving future marketing strategies by JNE. To create customer satisfaction, JNE can maintain the image that has been known to the public, superior, good, reputable, and give a good impression in their customer's minds.

\section{Relationship between brand image and customer trust}

Result of regression test on the relationship between brand image and customer trust indicates that brand image have positive and significant effect to customer trust ( $\beta$ $=0.390 ; \mathrm{S} . \mathrm{E}=0.068 ; \mathrm{C} . \mathrm{R}=5.718$ ). It can be interpreted that the better the brand image of JNE will leads to the higher customer trust in JNE. The results obtained from this study indicate that brand image and trust tend to have a relationship, so $\mathrm{H} 4$ is supported.

This phenomenon supports previous research conducted by Halim et al. (2014). The results of this study show a positive and significant impact of brand image on trust. Although the context of this study is different, but the results provide the fact that the influence of brand image on customer trust tend to be positive.

The results of the positive and significant effects derived from this research can be used as a basis for improving future marketing strategies by JNE. To create trust, JNE can maintain the image it already has because a good image will provide a high level of customer trust.

\section{Relationship between customer satisfaction and customer loyalty}

The result of regression testing on the relationship between customer satisfaction and customer loyalty indicates that customer satisfaction has positive and significant effect on customer loyalty $(\beta=0.225 ; \mathrm{S} . \mathrm{E}=0.060$; $\mathrm{C} . \mathrm{R}=3.760)$. This means that the higher customer satisfaction with JNE, the higher the customer's intention to be loyal to JNE. The results obtained from this study indicate that customer satisfaction and customer loyalty tend to have a relationship, so H5 is supported.

This phenomenon supports previous research conducted by Yu et al. (2012), that 
customer satisfaction has a strong impact on customer loyalty. Although this research is in different contexts but the results provide the fact that the effect of customer satisfaction on customer intent to loyal to JNE in fact tends to be positive.

The results that show positive and significant effects in this research can be used as a basis for improving future marketing strategies by JNE. To create customer intentions to be loyal, JNE can provide satisfying, proud, joyful, exhilarating, and exceed customer expectations that will create customer intentions to be loyal to JNE.

\section{Relationship between customer trust and customer loyalty}

The result of regression testing on the relationship between customer trust and customer loyalty show that customer trust has positive and significant effect on customer loyalty $(\beta=0.616 ; S . E=0.085 ; C . R=7.235)$. This can be interpreted that the higher customer trust in JNE will leads to the higher customer's intention to be loyal to JNE. The results obtained from this study indicate that customer trust and customer loyalty tend to have a relationship, so $\mathrm{H} 6$ is supported.

This phenomenon supports previous research conducted by Halim et al. (2014) that trust has a significant effect on customer loyalty. Companies need to pay attention to the trust expected by customers to be able to shape customer loyalty. Although the context of this study is different but the results provide the fact that the influence of customer trust in customer intention to be loyal to JNE in fact tend to have a positive influence.

The positive and significant results in this research can be used as a basis for improving future marketing strategies by JNE. In order to create customer loyalty, JNE can provide a service that is convincing, safe, secure, trustworthy, and honest to their customer so as to create customer intention to be loyal to JNE.

\section{CONCLUSIONS AND IMPLICATIONS}

\section{Conclusions}

Based on the results of research analysis that has been described previously and supported by the data obtained, in this study customer intention to be loyal to JNE is influenced by service quality, brand image, customer satisfaction, and customer trust. The relationship between these variables shows a significant and positive relationship.

Service quality in this study has a positive relationship with customer satisfaction and trust. If service quality provided by JNE is good, customers will be satisfied and trust JNE, this can create loyalty to JNE. In addition to service quality, brand image also has a positive relationship with customer satisfaction and trust. A good brand image will increase customer satisfaction and trust that will create loyalty to JNE.

\section{Implications}

The model in this study is developed based on previous research using two exogenous variables, two mediation variables, and one endogenous variable. Research with such a model is still rarely performed, so theoretically this research contributes to previous research with different models.

The results show that service quality and brand image affect customer loyalty mediated by customer satisfaction and trust. These results are expected to contribute particularly to the manager of JNE in determining their future strategy. Managers can improve their quality of services by paying attention to reliability, responsiveness, assurance, empathy, and concrete manifestations of JNE customers. In addition to service quality JNE also need to maintain brand image in the eyes of customers. Some things that 
can be done is to maintain a good image that has been owned, while maintaining the brand to remain known, superior, reputable, and provide a good impression in the eyes of customers.

Good service quality and brand image will satisfy customers. Customer satisfaction usually arises because customers feel the service they receive exceeds expectations so they feel proud, happy, and happy after using the JNE service. Satisfaction is not the only feeling that will arise from a customer when the quality of service and brand image of JNE is well preserved. Customers usually reuse or loyal when they feel confident with the service. Trust can be formed if services offered are guaranteed, honest, safe, reliable, and can convince customers.

The research model with two exogenous variables, two mediating variables, and one endogenous variable in this study tend to be rarely used. For future research, it is expected to develop existing models with different set of variables. In addition, although the overall results of this study are positively and significantly correlated with the goodness of fit test, some are not yet fit. Hopefully, future research can use a larger sample compared to this study in order to achieve better goodness of fit for each criteria.

\section{REFERENCES}

Akbar S. and Ahmad P.M.S. (2011). Determinants of customers loyalty for hospitality industry. Information Management and Business Review, Vol. 2, No. 1, Pp. 19-25.

Baig A.J., and Abdul R.B. (2014). Impact of Customer Satisfaction, Brand Image and Advertisements on Brand Loyalty of "Sting (Energy drink)" with Special Focus on Karachi European. Journal of Business and Management, Vol. 6, No. 37, Pp. 49-56.

Chao R.F., Tai C.W., and Wei T.Y. (2015). The Influence of Service Quality, Brand Image, and Customer Satisfaction on Customer Loyalty for Private Karaoke Roomsin Taiwan. The Journal of Global Business Management, Vol. 11, No. 1, Pp. 59-67.

Danesh S. N., Saeid A.N., and Kwek C. L. (2012). The Study of Customer Satisfaction, Customer Trust and Switching Barriers on Customer Retention in Malaysia Hypermarkets. International Journal of Business and Management, Vol. 7, No. 7, Pp. 141-150.

Davies G., and Chun, R. (2002). Gaps between the Internal and External Perceptions of the Corporate Brand. Corporate Reputation Review, Vol. 5, Issue. 2, Pp. 144-158.

Doney P. M., and Joseph P. C. (1997). An Examination of the Nature of Trust in BuyerSeller Relationships. Journal of Marketing, Vol. 61, Pp. 35-51.

Ferdinand, A. (2002). Structural Equation Modeling dalam Penelitian Manajemen. Semarang: Fakultas Ekonomi Undip

Halim P., Bambang S., Djamhur H., and M.Riza F. (2014). The Influence of Product Quality, Brand Image, and Quality of Service to Customer Trust and Implication on Customer Loyalty (Survey on Customer Brand Sharp Electronics Product at the South Kalimantan Province). European Journal of Business and Management, Vol. 6, No. 29, Pp. 159-166.

Hafeez S. and Bakhtiar M. (2012). The Impact of Service Quality, Customer Satisfaction and Loyalty Programs on Customer's Loyalty: Evidence from Banking Sector of Pakistan. International Journal of Business and Social Science, Vol. 3, No. 16, Pp. 200209. 
Harris, L. C., and Mark M. H. G. (2004). The Four Levels of Loyalty and The Pivotal Role of Trust: A Study of Online Service Dynamics. Journal of Retailing, Vol. 80, Issue 2, Pp. 139-158.

Kambiz S., and Naimi, S.S. (2014). The Impact of Brand Image on Customer Satisfaction and Loyalty Intention (Case Study: Consumer of Hygiene Products). International Journal of Engineering Innovation \& Research, Vol. 3, Issue. 1. Pp. 57-61.

Kimchuk, R.A., and Sandra A.K. (2007). Desain Kemasan Perencanaan Merek Produk yang Berhasil Mulai dari Konsep sampa Penjualan. Jakarta: Erlangga

Kotler P., and Gary A. (2001). Prinsip-prinsip Pemasaran edisi 8 jilid 1-2. Jakarta: Erlangga Lovelock C., Jochen W., and Jacky M. (2013). Pemasaran Jasa Jilid 2. Jakarta: Erlangga.

Leonidou, L. C., Michael A. T., and Constantinos N. L. (2008). Exercised Power as A Driver of Trust and Commitment in Cross-Border Industrial Buyer - Seller Relationships. Industrial Marketing Management, Vol. 37, Issue 1, Pp. 92-103.

Lupiyoadi, R., and A. Hamdani (2009). Manajemen Pemasaran Jasa. Jakarta: Salemba Empat

Morgan, R.M., and Shelby D. H. (1994). The commitment-trust theory of relationship marketing. Journal of Marketing, Vol. 58, Pp. 20-38.

Mosahab R., Osman M., and T. Ramayah. (2010). Service Quality, Customer Satisfaction and Loyalty: A Test of Mediation. International Business Research, Vol. 3, No. 4, Pp 72-80.

Naik, C. N. K., Swapna B. G., and Ganstasala V. P. (2010). Service Quality (SERVQUAL) and its Effect on Customer Satisfaction in Retailing. European Jurnal of Social Sciences, Vol. 16, N0. 2, Pp. 231-242.

Nejad L.R., Zahra F., and Amin T. (2014). Service Quality, Relationship Quality and Customer Loyalty (Case Study: Banking Industry in Iran). Open Journal of Social Sciences, Vol. 2, Pp. 262-268.

Neupane. R. (2015) The Effects Of Brand Image On Customer Satisfaction And Loyalty Intention In Retail Super Market Chain UK. International Journal of Social Sciences and Management. Vol. 2, Issue. 1, Pp. 9-26.

Oliver R.L. (1997), Satisfaction: Behavioral Perspective on the Consumer. McGraw- Hill, New York, NY.

Onyancha G.K. (2013). The Impact of Bank Brand Image on Customer Satisfaction and Loyalty: A Case of Kenya Commercial Bank. European Journal of Business and Management, Vol. 5, No. 21, Pp. 35-39.

Palvia, P. (2009). The Role of Trust in e-Commerce Relational Exchange: A Unified Model. Information \& Management, Vol. 46, Pp. 213-220.

Parasuraman, A., Valarie A.Z., and Leonard L.B. (1988). SERVQUAL: A multiple-item scale for measuring consumer perceptions of service quality. Journal of Retailing, Vol. 64, No. 1, Pp. 12-40.

Rai A.K., and Srivastava M. (2013). The Antecedents of Customer Loyalty: An Empirical Investigation in Life Insurance Context. Journal of Competitiveness, Vol. 5, Issue 2. Pp. 139-163.

Ribbink D., Allard C. R. V. R., Veronica L., and Sandra S. (2004). Comfort Your Online Customer: Quality, Trust and Loyalty on The Internet. Managing Service Quality: An International Journal, Vol. 14, Issue: 6, Pp. 446-456.

Saravanakumar G., and Jothi J. (2014). Effect of Service Quality on Customer Loyalty: Empirical Evidence from Co-Operative Bank. International Journal of Business and Administration Research, Vol. 2, Issue. 4, Pp. 87-94. 
Sarwar M.Z; Kashif S.A; and Saleem P. (2012). The Effect of Customer Trust on Customer Loyalty and Customer Retention: A Moderating Role of Cause Related Marketing. Global Journal of Management and Business Research. Vol. 12, Issue 6, Pp. 26-36.

Setiyawati, S. and Budhi H. (2016) Why Customers Intend to Use Express Delivery Services. Case Studies in Business and Management, Vol. 3, No. 2, Pp. 56-81.

Tjiptono F., and Gregorius C. (2011). Service, Quality \& Satisfaction Edisi 3. Yogyakarta: CV Andi Offset.

Tu Y.T., Chin M.W., and Hsiao C.C. (2012). Corporate Brand Image and Customer Satisfaction on Loyalty: An Empirical Study of Starbucks Coffee in Taiwan. Journal of Social and Development Sciences, Vol. 3, No. 1, Pp. 24-32. 